\title{
PELAKSANAAN REKRUTMEN PERANGKAT DESA
}

\author{
Fitri Widayanti \\ Fakultas IImu Sosial dan IImu Politik Universitas PGRI Palangka Raya \\ (email: f3widayanti@gmail.com)
}

\begin{abstract}
Abstrak
Penelitian ini dilaksanakan dengan Tujuan Penelitian adalah 1) Untuk mendeskripsikan Pelaksanaan Rekrutmen Perangkat Desa di Kabupaten Kotawaringin Timur, khususnya di Desa Karang Sari. 2) Untuk mengetahui Kendala yang dihadapi dalam Pelaksanaan Rekrutmen Perangkat Desa di Desa Karang Sari. Penelitian ini berlangsung kurang lebih 3 bulan dan berlokasi di Desa Karang Sari Kecamatan Parenggean. Tipe penelitian yang digunakan adalah tipe penelitian kualitatif deskriptif yaitu untuk eksplorasi dan klarafikasi mengenai suatu fenomena atau kenyataan sosial dengan menggunakan teknik pengumpulan data yang dilakukan dengan menggunakan teknik wawancara, studi dokumen, studi pustaka dan observasi.

Hasil penelitian: Pelaksanaan rekrutmen perangkat desa di Desa Karang Sari pada tahun 2018 dilakukan melalui proses seleksi yang dilaksanakan oleh Panitia Penjaringan Perangkat Desa, hasil dari seleksi calon perangkat desa yaitu dengan nilai kumulatif tertinggi kemudian dimintakan rekomendasi kepada Camat Parenggean, selanjutnya Camat Parenggean mengirimkan Surat Rekomendasi Perangkat Desa kepada Kepala Desa Karang Sari untuk memilih 6 (enam) orang peserta yang kemudian diangkat menjadi perangkat desa dengan Surat Keputusan Kepala Desa.
\end{abstract}

\section{Kata kunci : Pelaksanaan Rekrutmen Perangkat Desa}

\section{Pendahuluan}

Penjelasan mengenai desa dalam undang-undang Desa nomor 6 tahun 2014 telah menggambarkan bentuk keseriusan Pemerintah Pusat untuk membangun dan memperhatikan Indonesia dari Desa, dijelaskan bahwa Desa adalah desa dan desa adat atau yang disebut dengan nama lain, selanjutnya disebut Desa, adalah kesatuan masyarakat hukum yang memiliki batas wilayah yang berwenang untuk mengatur dan mengurus urusan pemerintahan, kepentingan masyarakat setempat berdasarkan prakarsa masyarakat, hak asal usul, dan atau/ hak tradisional yang diakui dan dihormati dalam sistem pemerintahan Negara Kesatuan Republik Indonesia. Indonesia memiliki 70 ribu lebih desa, dari total keseluruhan desa yang terletak diseluruh pedalaman Indonesia. Baik itu desa yang masih tertinggal hingga desa yang sudah maju dan berkembang serta mampu menyejahterakan masyarakatnya tanpa banyak campur tangan pemerintah pusat. Desa merupakan

\section{Jurnal Sociopolitico}


prioritas pembangunan pemerintah saat ini, karena dengan memajukan dan menyejahterakan masyarakat desa adalah bagian dari ukuran keberhasilan Indonesia dalam pembangunan. Berbicara masalah desa, setidaknya ada 4 (empat) masalah pokok pembangunan pedesaan yang saling berkaitan satu sama lain, yakni masalah kemiskinan, kesehatan, peningkatan kualitas sumber daya manusia, dan infrastruktur sebagai penunjang mobilitas masyarakat desa. Untuk menyelesaikan masalah pokok pembangunan tersebut, tentu merupakan tanggung jawab dari seluruh elemen masyarakat dan pemerintah desa.

Setiap proses dan dinamika pembangunan desa tentu adanya hasil yang diharapkan dapat menyelesaikan permasalahan yang ada di desa. Dengan adanya pelimpahan kewenangan dan hak penuh terhadap desa melalui UndangUndang Nomor 6 Tahun 2014 Tentang Desa, diharapkan seluruh desa yang ada di Indonesia mampu membangun kemandirian dan kesejahteraan masyarakat desa. Dalam undang-undang desa telah diatur sedemikian rupa terkait bagaimana peran dan fungsi serta partisipasi aparatur pemerintah desa maupun masyarakat untuk mewujudkan kemajuan dan kemandirian desa. Tidak hanya itu, kapasitas dari elemen pemerintahan desa maupun masyarakat juga menjadi tolok ukur dari kemajuan desa. Oleh karena itu, sangat diharapkan setiap desa memiliki aparatur pemerintah dan perangkat desa yang mempunyai kapasitas mumpuni dibidangnya masing-masing, artinya kemampuan menguasai tugas dan tanggung jawab yang di emban oleh aparatur dan perangkat desa serta kemampuan melihat maupun menafsirkan peluang yang bisa dicapai untuk kemajuan desa. Permasalahan yang banyak terjadi di Desa bahkan mencakup keseluruhan pinggiran Indonesia adalah kurangnya kompetensi yang dimiliki oleh aparatur pemerintah Desa.

Kesulitan yang terjadi mengenai kapasitas maupun kompetensi yang dimiliki oleh perangkat desa yang ada di sebagian maupun kebanyakan daerah yang ada di Indonesia adalah bagaimana pelaksanaan seleksi Perangkat Desa yang ada di setiap desa, karena tidak sedikit masyrakat desa yang ingin dan mengikuti seleksi untuk menjadi perangkat desa, bahkan banyak masalah yang terjadi saat proses seleksi perangkat desa, misalnya banyak masyarakat yang mengikuti proses seleksi tetapi tidak memiliki latar belakang, maupun kapasitas dibidangnya, belum lagi beberapa kerjasama ataupun nepotisme yang sering diterapkan.

Berbagai permasalahan dalam proses seleksi perangkat desa di Indonesia, seperti yang terjadi di Kabupaten Kotawaringin Timur, Kecamatan Parenggean, warga mengadu terkait adanya rekayasa dalam proses Penjaringan dan Penyaringan Perangkat Desa (P3D) ditempatnya. "Saya katakan terindikasi syarat rekayasa karena yang jadi sebelumnya sudah ditunjuk sebelum tes P3D dilaksanakan," ungkap Aziz, Jumat (Juni 2018). Rekrutmen seleksi perangkat desa sendiri diikuti sebanyak 17 peserta. Namun, nama-nama yang lolos sudah ditentukan sebelum "Pengumumannya memang dilakukan Selasa sore, tapi di surat keputusan kelolosan ditandatangani hari Senin. Itu artinya ujian hari kedua hanya formalitas saja," katanya. "Tujuannya, untuk menguatkan posisi Kepala Desa yang akan kembali maju pada Pilkades mendatang”.

\section{Jurnal Sociopolitico}


$\begin{array}{cll}\text { Berbagai } & \text { cara dilakukan } & \text { untuk } \\ \text { memuluskan } & \text { kecurangan } & \text { dalam }\end{array}$ pelaksanaan seleksi perangkat desa yang dilakukan panitia pelaksana, seperti yang terjadi di Kecamatan Parenggean, Kabupaten Kotawaringin Timur. Adanya dugaan jual beli jabatan perangkat desa dengan tujuan untuk menguatkan posisi Kepala Desa pada Pemilihan Kepala Desa mendatang. Persoalan seperti ini sedikit sulit untuk dibawa ke ranah hukum, mengingat bukti-bukti yang mudah terselubung dengan rupiah dan kecurangan yang sudah tersistem sedemikian rupa.

Aroma tak sedap juga tercium dalam proses pengisian kursi jabatan perangkat desa secara serentak di Desa lainnya. Salah satunya indikasi adanya tawar menawar jabatan sebelum proses seleksi dimulai. Informasi yang dihimpun dari sejumlah sumber menyebutkan tawar menawar kursi perangkat desa terjadi antara calon peserta tes dengan pemangku kepentingan di daerah yang bersangkutan. Tawar menawar itu dilakukan di luar lingkungan desa dan tertutup. Ada yang by phone, bertemu langsung, maupun melalui perantara. Salah satu warga SS menyebutkan praktik curang "rekomendasi" juga mewarnai proses pengisian jabatan perangkat desa. Sebelum proses seleksi dilakukan sudah ditentukan siapa yang "direkomendasikan" menduduki kursi perangkat desa itu. "Jadi orang-orang yang direkomendasikan untuk menduduki perangkat desa sudah ada sebelum ada seleksi. Tentu saja, harus dengan tebusan," tambahnya.

Salah satu sumber dari lainnya juga mengemukakan hal serupa. Ia mengaku batal mendaftar karena digugurkan sepihak oleh pemangku kepentingan di wilayah setempat. "Saya menyanggupi bayar puluhan juta untuk lowongan sekretaris desa, tapi tiba-tiba saya dibatalkan karena ada peserta lain yang berani membayar lebih tinggi. Saya lantas ditawari kursi lainnya, tapi saya enggak mau," ujarnya.

Berbagai kecurangan terjadi dalam pelaksanaan seleksi perangkat desa di Indonesia, mulai dari penggunaan rekomendasi dari oknum yang berkuasa disuatu Desa hingga pembelian jabatan perangkat desa dengan rupiah atau money politic, untuk menguatkan posisi Kepala Desa yang menjabat, maupun persiapan menghadapi pemilihan Kepala Desa pada periode yang akan datang. Pada intinya bertujuan untuk memperoleh kekuasaan, tak terkecuali di Kabupaten Kotawaringin Timur, pernah terjadi kejanggalan dalam pelaksanaan seleksi perangkat desa hingga mantan peserta seleksi pernah mendatangi Dewan Perwakilan Rakyat Daerah (DPRD) untuk mempertanyakan prosedur yang seharusnya dalam seleksi yang tidak sesuai dengan Peraturan Bupati.

Berbagai kasus di atas menggambarkan permasalahan utama bahwa kualitas sumber daya manusia sebagai perangkat desa yang masih rendah, adanya beberapa kasus pergantian kepala desa juga menggati perangkat desa tanpa melalui seleksi dan adanya berbagai kasus seleksi yang dilakukan tapi penuh kecurangan dengan politik uang, nepotisme. Selain itu, masyarakat juga belum memahami peraturan yang baru mengenai pengisian perangkat desa, terlebih RT harus melalui seleksi bukan pemilihan secara langsung oleh masyarakat, sehingga perlu adanya sosialisasi oleh pemerintah desa Karang Sari kepada masyarakat.

Studi ini menjadi penting untuk dilakukan karena kaitannya dengan ilmu Politik untuk mengetahui persoalan dalam

\section{Jurnal Sociopolitico}


pelaksanaan rekrutmen perangkat desa. Dari latar belakang tersebut maka peneliti tertarik untuk mendeskripsikan "Pelaksanaan Rekrutmen Perangkat Desa".

\section{Metode Penelitian}

Penelitian ini menggunakan jenis penelitian kualitatif. Menurut Meoleong (2012) penelitian kualitatif merupakan penelitian yang mempunyai maksud untuk memahami fenomena tentang apa yang dialami oleh subyek penelitian secara holistik serta dengan cara deskripsi dalam bentuk kata-kata dan bahasa, pada suatu konteks khusus secara alamiah dengan memanfaatkan berbagai metode alamiah.

\section{Hasil dan Pembahasan}

\section{Proses Rekrutmen Perangkat Desa Karang Sari}

Proses rekrutmen merupakan cara memanajemen karyawan atau pegawai dalam sebuah organisasi agar dapat menjalankan sebuah organisasi secara efektif. Secara teoritis, unsur manajemen meliputi man, money, methods, materials, machine, market. Unsur manusia sebagai penggerak utama organisasi/lembaga yang harus melalui proses seleksi terlebih dahulu sehingga dikenal manajemen kepegawaian. Dalam pembahasan ini, penulis lebih menekankan unsur manusia sebagai faktor penentu dalam sebuah proses seleksi berdasarkan indikator yang telah ditentukan.

Karyawan atau pegawai adalah aset utama atau pelaku utama yang menjadi perencana, pembuat keputusan dan pelaku aktif dari organisasi. Mereka memiliki pikiran, keinginan, perasaan, status, latar belakang pendidikan, usia, dan jenis kelamin yang heterogen. Mereka bukanlah mesin, uang, dan material yang sifatnya pasif dan dapat diatur sepenuhnya dalam mendukung tercapainya tujuan. Kemampuan dan keterampilan pegawai belum menjamin produktivitas kerja yang baik jika moral kerja dan kedisiplinannya rendah. Mereka dapat dikatakan bermanfaat mendukung terwujudnya tujuan jika mereka berkeinginan tinggi untuk berprestasi.

Kualitas dan kuantitas pegawai harus sesuai dengan kebutuhan agar menunjang tercapainya tujuan secara efektif dan efisien. Penempatan tenaga kerja juga harus tepat sesuai dengan kapasitasnya. Dengan demikian, gairah kerja dan kedisiplinannya akan lebih baik serta efektif menunjang terwujudnya tujuan organisasi. Oleh karena itu, pengadaan karyawan atau pegawai harus didasarkan pada prinsip apa baru siapa. Apa artinya menetapkan terlebih dahulu pekerjaan-pekerjaannya berdasarkan uraian pekerjaan (job description). Siapa artinya mencari pegawai yang tepat untuk menduduki jabatan tersebut berdasarkan spesifikasi pekerjaan (job specification).

Pengadaan pegawai berdasarkan siapa kemudian apa, menimbulkan ketidakcocokan atau mismanajemen dalam penempatan. Penempatan pegawai yang jauh di luar kemampuannya mengakibatkan moral kerja, semangat kerja dan kedisiplinan menjadi rendah. Adapun proses rekrutmen pegawai (Utami, 2015:30-31), yaitu (1) Peramalan kebutuhan tenaga kerja; (2) Penarikan (recruitment); (3) Seleksi (selection); dan (4) Penempatan, orientasi, dan induksi karyawan atau pegawai.

Perekrutan pegawai hendaknya dilakukan dengan baik dan benar sehingga pegawai yang diterima sesuai dengan

\section{Jurnal Sociopolitico}


kebutuhan pekerjaan yang akan dilakukan. Dalam penelitian ini, penulis menjelaskan tentang proses rekrutmen perangkat desa bahwa keterlibatan partisipasi masyarakat luas sangatlah penting terhadap dalam proses rekrutmen perangkat desa sebagai wujud dari kehidupan demokrasi.

Rekrutmen menurut Sukamti (1989:133) adalah serentetan kegiatan oleh organisasi untuk menarik calon pegawai yang memiliki kemampuan dan sikap yang dibutuhkan dalam mencapai tujuan. Selanjutnya, istilah rekrut berarti serentetan kegiatan atau rangkaian kegiatan dan proses sah untuk mendapatkan orang-orang yang tepat dalam jumlah yang cukup. Jadi rekrutmen adalah sebuah proses dalam mendapatkan sejumlah orang dengan kriteria tertentu untuk menghasilkan kualitas tertentu pula di bidang kemampuannya untuk bekerja di organisasi atau lembaga yang menyediakan fasilitas perekrutan.

Proses rekrutmen perangkat Desa Tiremenggal sendiri telah diatur dalam Keputusan Kepala Desa No 141 Tahun 2018 Tentang penetapan formasi pengadaan dan syarat perangkat desa baru di desa karang sari yaitu masyarakat yang dapat diangkat menjadi Perangkat Desa adalah penduduk desa setempat Warga Negara Republik Indonesia yang (1) Bertakwa kepada Tuhan Yang Maha Esa; (b) Setia kepada Pancasila sebagai Dasar Negara, Undang-Undang Dasar Negara Republik Indonesia Tahun 1945, Negara Kesatuan Republik Indonesia, dan Pemerintah; (c) Berusia paling rendah 20 (dua puluh) tahun dan paling tinggi 60 (enam puluh) tahun, dibuktikan dengan Akta kelahiran atau alat keterangan pembuktian kelahiran yang lain, terhitung pada saat penutupan pendaftaran; (d) Berpendidikan paling rendah Sekolah
Lanjutan Tingkat Pertama dan/atau sederajat, yang dibuktikan dengan ijazah/Surat Tanda Tamat Belajar (STTB) pendidikan formal dari tingkat dasar sampai dengan ijazah/STTB terakhir yang dilegalisir oleh pejabat yang berwenang; (f) Bersedia bertempat tinggal tetap di Desa setempat; (g) Bertempat tinggal di wilayah kerjanya, bagi Calon Kepala Dusun; (h) Sehat jasmani dan rohani, dibuktikan dengan surat keterangan dokter dari Rumah Sakit Pemerintah atau Puskesmas setempat; (i) Berkelakuan baik, dibuktikan dengan surat keterangan catatan kepolisian atau keterangan lain dari Kepolisian Sektor setempat; (j) Tidak pernah dihukum karena melakukan tindak pidana kejahatan yang ancaman pidananya minimal 5 tahun penjara berdasarkan keputusan pengadilan yang telah memperoleh kekuatan hukum tetap yang dibuktikan dengan surat pernyataan; (k) Terdaftar sebagai penduduk desa setempat paling sedikit 2 (dua) tahun terakhir berturut-turut, dibuktikan dengan Kartu tanda Penduduk (KTP) atau Kartu Keluarga (KK), kecuali bagi putra desa.

Dengan dilaksanakannya proses rekrutmen perangkat Desa Karang Sari maka dibentuk tim Penjaringan dan Penyaringan Perangkat Desa (P3D) dengan tugas sebagaimana pada Surat Keputusan Kepala Desa Nomor 141 tahun 2018 yakni menyusun jadwal kegiatan; mengelola anggaran secara efisien, efektif, transparan dan akuntabel; serta menyusun tata tertib sesuai dengan ketentuan peraturan perundangundangan. Kemudian, melaksanakan sosialisasi lowongan perangkat desa kepada masyarakat; melaksanakan penjaringan/pendaftaran bakal calon perangkat desa; melaksanakan penyaringan/ujian seleksi calon perangkat desa; dan menyiapkan tempat ujian calon

\section{Jurnal Sociopolitico}


perangkat desa. Selanjutnya, melaksanakan penilaian hasil ujian calon perangkat desa; melaksanakan tertib administrasi pelaksanaan penjaringan dan penyaringan perangkat desa; menyampaikan laporan kepada kepala desa untuk setiap tahapan pelaksanaan penjaringan dan penyaringan perangkat desa disertai berita acara dan menyampaikan informasi kepada masyarakat; memperlakukan bakal calon perangkat desa secara adil dan setara; melaksanakan tahapan pelaksanaan penjaringan dan penyaringan perangkat desa tepat waktu; dan mempertanggungjawabkan penggunaan anggaran kepada Kepala Desa.

\section{Syarat Penjaringan dan Penyaringan Perangkat Desa Karang Sari Berdasarkan Peraturan Kepala Desa No. 05 Tahun 2018}

1. Calon Perangkat Desa dalam penjaringan dan penyaringan Perangkat Desa adalah Warga Negara Republik Indonesia dengan syarat sebagai berikut:

1. Bertaqwa kepada Tuhan Yang Maha Esa;

2. memegang teguh dan mengamalkan Pancasila, melaksanakan Undang-Undang Dasar Negara Republik Indonesia Tahun 1945, serta mempertahankan dan memelihara keutuhan Negara Kesatuan Republik Indonesia dan Bhinneka Tunggal Ika;

3. berpendidikan paling rendah Sekolah Menengah Umum atau yang sederajat;

4. berusia 20 (dua puluh) tahun sampai dengan 42 (empat puluh dua) tahun pada saat pendaftaran;
5. untuk pengisian Sekretaris Desa, dapat diikuti oleh Perangkat Desa aktif dengan maksimal berusia 42 (empat puluh dua) tahun pada saat pendaftaran;

6. penduduk Warga Negara Republik Indonesia yang dibuktikan dengan Kartu Keluarga dan Kartu Tanda Penduduk;

7. sehat jasmani dan rohani serta bebas Narkotika, Psikotropika, Zat Adiktif lainnya yang dibuktikan dengan Surat Keterangan Dokter pemerintah;

8. berkelakuan baik yang dibuktikan dengan Surat Keterangan dari Kepolisian;

9. tidak pernah dihukum karena melakukan tindak pidana yang diancam dengan hukuman penjara paling singkat 5 (lima) tahun yang dibuktikan dengan Surat Keterangan dari Pengadilan Negeri;

10. tidak sedang dicabut hak pilihnya sesuai dengan putusan Pengadilan yang mempunyai kekuatan hukum tetap yang dibuktikan dengan Surat Keterangan dari Pengadilan Negeri;

11. berkelakuan baik, jujur dan adil;

12. tidak pernah mengundurkan diri dari jabatan Kepala Desa atau Perangkat Desa;

13. tidak pernah diberhentikan dari jabatan Kepala Desa, Perangkat Desa, CPNS, PNS, Anggota TNI/POLRI serta BUMN/BUMD;

14. bersedia bertempat tinggal di desa yang bersangkutan selama menjabat Perangkat Desa dan khusus untuk Kepala Dusun 
bersedia bertempat tinggal di wilayah dusun tersebut.

2. Pegawai Negeri Sipil yang akan mengikuti penjaringan Perangkat Desa harus mendapatkan izin tertulis dari pejabat pembina kepegawaian.

3. Perangkat Desa yang akan mengikuti penjaringan Sekretaris Desa sebagaimana dimaksud pada ayat (1) huruf e, harus memberitahukan secara tertulis kepada Kepala Desa masingmasing.

4. Dalam hal Pegawai Negeri Sipil sebagaimana dimaksud pada ayat (2) terpilih dan diangkat menjadi Perangkat Desa, yang bersangkutan dibebaskan sementara dari jabatannya selama menjadi Perangkat Desa tanpa kehilangan hak sebagai Pegawai Negeri Sipil.

5. Anggota BPD yang akan mengikuti penjaringan Perangkat Desa harus mendapatkan izin tertulis dari pimpinan BPD, sedang bagi pimpinan BPD harus mendapat izin dari Camat.

\section{Pendaftaran}

1. Jangka waktu pendaftaran dilaksanakan selama 14 (empat belas) hari.

2. Apabila dalam jangka waktu dimaksud belum mendapatkan Bakal Calon, maka jangka waktu pendaftaran diperpanjang untuk selama 7 (tujuh) hari

3. Dalam hal setelah perpanjangan dilaksanakan, tetap tidak mendapatkan Bakal Calon, maka dilakukan pendaftaran dari awal.

4. Perpanjangan atau pendaftaran dari awal, diumumkan oleh Panitia paling lama pada hari pertama perpanjangan/pendaftaran dari awal dengan membuat Berita Acara.

5. Pendaftaran Bakal Calon dilakukan dengan menyerahkan lamaran yang diajukan secara tertulis di atas kertas segel/bermeterai cukup kepada Kepala Desa melalui Panitia, dengan melampirkan:

6. Surat Pernyataan yang memuat:

a) bertaqwa kepada Tuhan Yang Maha Esa;

b) setia dan taat kepada Pancasila sebagai dasar negara, Undang-

Undang Dasar Negara Republik Indonesia Tahun 1945, dan Negara Kesatuan Republik Indonesia serta Pemerintah;

c) sanggup berbuat baik, jujur, dan adil;

d) tidak sedang menjalani pidana penjara dengan hukuman badan atau hukuman percobaan;

e) tidak sedang berstatus tersangka atau terdakwa karena tindak pidana yang diancam dengan pidana penjara;

f) sanggup mengundurkan diri dari jabatan lama apabila diangkat dalam jabatan baru, bagi anggota BPD dan Perangkat Desa;

g) bersedia bertempat tinggal di desa yang bersangkutan selama menjabat Perangkat Desa dan khusus untuk Kepala Dusun bersedia bertempat tinggal di wilayah dusun tersebut

h) fotokopi/salinan ijazah dari tingkat dasar sampai dengan ijazah terakhir yang dilegalisasi oleh pejabat yang berwenang;

7. fotokopi/salinan akta kelahiran atau Surat Keterangan Kenal Lahir yang dilegalisir pejabat berwenang; 
8. fotokopi Kartu Tanda Penduduk yang dilegalisir dan surat keterangan bertempat tinggal sebelum pendaftaran dari Rukun Tetangga/Rukun Warga dan Kepala Desa setempat;

9. fotokopi Kartu Keluarga (C1) yang dilegalisir;

10. Surat Keterangan Catatan Kepolisian yang dikeluarkan oleh kepolisian setempat;

11. Surat Keterangan dari Pengadilan Negeri yang menerangkan Bakal Calon tidak pernah dihukum karena melakukan tindak pidana yang diancam dengan hukuman penjara paling singkat 5 (lima) tahun;

12. Surat Keterangan dari Pengadilan Negeri yang menerangkan Bakal Calon tidak sedang dicabut hak pilihnya sesuai dengan putusan Pengadilan yang mempunyai kekuatan hukum tetap;

13. Surat Keterangan Kesehatan yang dikeluarkan oleh Dokter Pemerintah yang menerangkan bahwa yang bersangkutan sehat jasmani dan rohani;

14. pas foto, warna dan ukuran yang banyaknya sesuai kebutuhan;

15. surat izin dari pejabat pembina kepegawaian bagi Pegawai Negeri Sipil; dan

16. bagi Perangkat Desa yang ikut penjaringan Sekretaris Desa harus melampirkan surat pemberitahuan dari Kepala Desa tempat tugasnya secara tertulis.

\section{Penetapan Calon}

1. Panitia melakukan penelitian persyaratan administrasi masingmasing Bakal Calon.

2. Apabila setelah diadakan penelitian persyaratan administrasi pendaftaran ternyata terdapat kekurangan dan keragu-raguanterkait persyaratan administrasi yang telah ditentukan, maka Panitia meminta Bakal Calon yang bersangkutan untuk melengkapi dan memberikan penjelasan.

3. Jangka waktu untuk melengkapi syarat administrasi dan memberikan penjelasan paling lama 3 (tiga) hari terhitung sejak pemberitahuan adanya kekurangan persyaratan.

4. Persyaratan administrasi Bakal Calon yang telah diteliti dan dinyatakan tidak memenuhi persyaratan administrasi yang telah ditentukan, maka suratlamaran beserta lampirannya dikembalikan oleh Panitia secara tertulis dengan disertai tanda bukti penerimaan dari Bakal Calon yang bersangkutan.

5. Bakal Calon yang telah melalui penelitian dan memenuhi persyaratan administrasi oleh Panitia ditetapkan sebagai Calon yang dituangkan dalam Berita Acara Penetapan Calon.

6. Nama-nama Calon selanjutnya diumumkan kepada masyarakat paling lambat 1 (satu) hari setelah ditetapkan untuk memberikan kesempatan masyarakat menilai masing-masing Calon.

\section{Penyampaian Keberatan Terhadap Calon}

1. Penyampaian keberatan terhadap Calon yang ditetapkan oleh Panitia Penjaringan dan Penjaringan disampaikan kepada Panitia dengan menyebutkan identitas pengirim secara jelas, paling lambat 7 (tujuh) hari sejak penetapan Calon.

2. Keberatan terhadap Calon berkaitan dengan persyaratan administrasi Calon. 
3. Penyampaian keberatan, setelah diteliti kebenarannya, dituangkan dalam Berita Acara Penelitian Keberatan Masyarakat oleh Panitia.

4. Berita Acara Penelitian Keberatan Masyarakat menjadi bahan pertimbangan dan masukan bagi Kepala Desa untuk menetapkan Calon yang Berhak Mengikuti Ujian.

5. Keberatan masyarakat yang berkaitan dengan persyaratan dan terbukti kebenarannya menggugurkan Penetapan Calon.

6. Penyampaian keberatan yang melebihi batas waktu tidak dipertimbangkan.

\section{Penetapan Calon Yang Berhak Mengikuti Ujian}

1. Panitia mengusulkan Calon kepada Kepala Desa dengan dilampiri Berita Acara Penetapan Calon dan Berita Acara Penelitian Keberatan Masyarakat untuk ditetapkan sebagai Calon yang berhak mengikuti ujian.

2. Kepala Desa setelah menerima usulan Panitia, menetapkan Calon yang berhak mengikuti ujian dengan mempertimbangkan Berita Acara Penetapan Calon dan/atau Berita Acara Penelitian Keberatan Masyarakat, yang dituangkan dengan Keputusan Kepala Desa.

3. Keputusan Kepala Desa, disampaikan kepada Ketua Panitia paling lambat 2 (dua) hari sebelum pelaksanaan ujian penyaringan.

4. Setelah Ketua Panitia menerima Keputusan Kepala Desa, pada hari itu juga, Panitia mengumumkan namanama Calon yang berhak mengikuti ujian.

\section{Penyaringan}

Calon yang berhak mengikuti Ujian wajib mengikuti ujian dan penilaianyang dilaksanakan oleh Panitia.

1. Ujian dan penilaian meliputi:

a) ujian penyaringan dilaksanakan secara tertulis dan uji kemampuan/praktek;

b) penilaian terhadap prestasi meliputi pendidikan dan kejuaraan/lomba, dan dedikasi.

17. Pada ujian penyaringan, Calon yang berhak mengikuti ujian dinyatakan lulus apabila memenuhi nilai minimal ujian.

18. Ketentuan mengenai ujian penyaringan dan nilai minimal ujian diatur lebih lanjut dalam tata tertib Panitia.

19. Hasil ujian dan penilaian diberi peringkat berdasarkan jumlah nilai yang diperoleh masing-masing Calon.

20. Materi ujian penyaringan meliputi Pancasila, Undang-Undang Dasar 1945, Nasionalisme, Pengetahuan Umum, Kepemerintahan, Administrasi Perkantoran, dan Kepemimpinan.

21. Ujian tertulis dilaksanakan dengan menggunakan soal pilihan ganda (multiplechoice), berjumlah 100 soal dan penilaian dilakukan dengan menggunakan angka satuan maksimal dengan nilai 100.

22. Pelaksanaan ujian tertulis dituangkan dalam Berita Acara Ujian Penyaringan oleh Panitia serta dapat dilengkapi tanda tangan Calon yang berhak Mengikuti Ujian.

a) Uji kemampuan/praktek terkait materi uji kemampuan mengoperasionalkan komputer dengan nilai skala $0-50$ atau berdasarkan kategori penilaian 
yang diatur lebih lanjut dalam tata tertib oleh Panitia.

b) Dalam hal pelaksanaan uji kemampuan/praktek Panitia dapat bekerjasama dengan pihak lain yang mempunyai kompetensi dibidang komputer.

Penilaian prestasi meliputi penilaian:

a) pendidikan; dan

b) kejuaraan/lomba.

Penilaian pendidikan mendasarkan ijazah atau Surat Tanda Tamat Belajar (STTB) tertinggi yang diraih Calon dengan kriteria penilaian sebagai berikut:

a) SMU/SMA/SMK/Sederajat nilai 6 (enam);

b) Diploma I (D1) nilai 7 (tujuh);

c) Diploma II (D2) `nilai 8 (delapan);

d) Diploma III (D3) nilai 9 (sembilan);

e) Strata 1 (S1) nilai 10 (sepuluh);

Pelaksanaan Tahapan Penetapan Calon Pelaksanaan tahapan penetapan calon menjadi calon terpilih sebagaimana dalam pasal 4 huruf e, dilakukan secara berjenjang dengan kegiatan:
a. Penyampaian laporan hasil pelaksanaan seleksi perangkat desa dari timsel kepada kepala desa;

b. Penyampaian laporan pelaksanaan seleksi perangkat desa dan konsultasi pengangkatan perangkat desa oleh kepala desa kepada camat; dan

c. Penyampaian tanggapan dan pemberian rekomendasi tertulis terhadap laporan kepala desa tentang pelaksanaan seleksi perangkat desa dari camat kepada kepala desa.

Timsel menyampaikan laporan hasil pelaksanaan seleksi perangkat desa yang telah dilaksanakan kepada kepala desa paling lambat 2 (dua) hari setelah penetapan hasil seleksi tertulis sebagaiman dimaksud dalam pasal 28 ayat 2, laporan pelaksanaan seleksi tertulis dari timsel kepada kepala desa sekurang-kurangnya memuat:

a. Data pribadi calon;

b. Pengalaman bekerja calon;

c. Tingkat pendidikan calon

d. Usia calon;

e. Nilai seleksi tertulis, dan/atau

f. Dasar pertimbangan lainnya.

Pelaksanaan kegiatan penyampaian laporan pelaksanaan seleksi perangkat desa dan konsultasi pengangkatan perangkat desa oleh kepala desa kepada camat, dengan ketentuan:

a. Kepala desa melaksanakan konsultasi hasil seleksi perangkat desa kepada camat dalam jangka waktu 3 (tiga) hari setelah diterimanya laporan dari timsel;

b. Dalam melaksanakan konsultasi sebagaimana dimaksud pada ayat 3 , huruf a, kepala desa menyampaikan secara tertulis kepada camat, dengan ketentuan:

1) Dasar pertimbangan disetujui atau tidak disetujui pengangkatan calon perangkat desa menjadi perangkat desa; dan

2) Data pribadi calon;

3) Pengalaman bekerja calon;

4) Tingkat pendidikan calon;

5) Usia calon; dan/atau

6) Dasar pertimbangan lainnya

Camat setelah menerima laporan kepala desa memberikan rekomendasi tertulis terhadap calon yang telah diusulkan dalam jangka waktu paling lama 7 (tujuh) hari kerja setelah laporan dan konsultasi diterima, dengan ketentuan: 
a. Rekomendasi yang diberikan camat dapat berupa persetujuan atau penolakan:

b. Rekomendasi yang diberikan camat berdasarkan pertimbangan camat dan/atau kepala desa serta persyaratan yang telah ditetapkan, dengan ketentuan:

1) Dalam hal camat memberikan persetujuan, kepala desa menerbitkan keputusan kepala desa tentang pengangkatan perangkat desa; atau

2) Dalam hal rekomendasi camat berisi penolakan, kepala desa melalui timsel melakukan seleksi perangkat desa kembali.

Dalam hal calon yang berpendidikan sekolah menengah pertama atau sederajat sebagaimana dimaksud dalam pasal 25 ayat 3 huruf c angka 2 huruf a yang terpilih dan diangkat menjadi perangkat desa, yang bersangkutan wajib menyelesaikan penyetaraan pendidikan dalam waktu paling lambat 2 (dua) tahun sejak pengambilan/pengucapan sumpah/janji perangkat desa.

Apabila bakal calon perangkat desa yang telah terpilih dan telah diangkat tidak melaksanakan kewajiban sebagaiman dimaksud pada ayat 1 dikenai sanksi administrative berupa pemberhentian dengan disertai pengembalian keuangan desa yang telah diterima atau digunakan selama menjabat sebagai perangkat desa.

Bagi pegawai negeri sipil (PNS) yang terpilih dan diangkat sebagai perangkat desa dibebas tugaskan dari jabatannya sebagai pegawai negeri sipil (PNS) selama menjabat sebagai perangkat desa tanpa kehilangan hak sebagai pegawai negeri sipil (PNS) sesuai ketentuan peraturan perundang-undangan.
Bagi badan permusyawaratan desa (BPD), lembaga adat, organisasi kemasyarakatan, pegawai pemerintah dengan perjanjian kerja, tenaga kontrak/honorer, tenaga kerja swasta, pengurus (Badan Usaha Milik Desa) (BUMDes) yang terpilih dan diangkat menjadi perangkat desa wajib mengundurkan diri sebelum pelantikan atau pengambilan sumpah/janji perangkat desa.

Perangkat desa yang bukan berasal dari penduduk desa setempat dan/atau tidak bertempat tinggal atau beralamatkan desa setempat pada identitas di kependudukannya berkewajiban menetap dan bertempat tinggal di desa setempat, dengan ketentuan:

a. Dalam jangka waktu 6 (enam) bulan setelah pengambilan/pengucapan sumpah/janji/pelantikan, perangkat desa wajib melakukan mutasi penduduk;

b. Dokumen mutasi penduduk sebagaimana dimaksud pada huruf a, disampaikan kepada kepala desa dan camat sebelum berakhirnya waktu sebagaimana dimaksud pada huruf a;

c. Dalam jangka waktu sebagaimana dimaksud pada huruf $b$, perangkat desa tidak melakukan mutasi penduduk, kepala desa memberhentikan perangkat desa dengan keputusan.

Pelaksanaan rekrutmen perangkat desa di Desa Karang Sari pada tahun 2018 dilakukan melalui proses seleksi yang dilaksanakan oleh Panitia Penjaringan Perangkat Desa, hasil dari seleksi calon perangkat desa yaitu dengan nilai kumulatif tertinggi kemudian dimintakan rekomendasi kepada Camat Parenggean, selanjutnya Camat Parenggean mengirimkan Surat Rekomendasi

\section{Jurnal Sociopolitico}


Perangkat Desa kepada Kepala Desa Karang Sari untuk memilih 6 (enam) orang peserta yang kemudian diangkat menjadi perangkat desa dengan Surat Keputusan Kepala Desa.

\section{Kesimpulan}

Pelaksanaan rekrutmen perangkat desa di Desa Karang Sari pada tahun 2018 dilakukan melalui proses seleksi yang dilaksanakan oleh Panitia Penjaringan Perangkat Desa, hasil dari seleksi calon perangkat desa yaitu dengan nilai kumulatif tertinggi kemudian dimintakan rekomendasi kepada Camat Parenggean, selanjutnya Camat Parenggean mengirimkan Surat Rekomendasi Perangkat Desa kepada Kepala Desa Karang Sari untuk memilih 6 (enam) orang peserta yang kemudian diangkat menjadi perangkat desa dengan Surat Keputusan Kepala Desa.

\section{Referensi}

Cst Kansil. Dan Christine ST Kansil, 2005. Sistem Pemerintahan Indonesia, Jakarta, Bumi Aksara

Husaini Usman dan Purnomo Setiady Akbar. 2006. Meteodologi Penelitian Sosial, PT. Bumi Aksara : Yogyakarta,

Irawan, Prasetya, Suryani S.F.Motok, Sri Wahyu Krida Sakti. 1997. Manajemen Sumber Daya Manusia, STIA LAN Press : Jakarta.

Kamus Besar Bahasa Indonesia,2013 Medan: Bitra Indonesia

Lexy J. Moleong. 2002. Metodologi Penelitian Kualitatif, PT Remaja Rosdakarya : Bandung.
Mathis. Robert I, Jackson John H. 2001. Manajemen Sumber Daya Manusia, Salemba Empat : Jakarta.

Samsudin, S. 2006. Manajemen Sumber Daya manusia, CV. Pustaka Setia : Bandung.

Siagian, P Sondang. 2006. Manajemen Sumber Daya Manusia, PT. Bumi Aksara : Jakarta.

Undang-Undang Republik Indonesia Nomor 6 Tahun 2014 Tentang Desa

Peraturan Pemerintah Nomor 43 Tahun 2014 Tentang Peraturan Pelaksanaan

Undang-Undang Nomor 6 Tahun 2014 Tentang Desa

Peraturan Menteri Dalam Negeri Republik Indonesia Nomor 84 tahun 2015 Tentang Susunan Organisasi Dan Tata Kerja Pemerintah Desa

Peraturan Menteri Dalam Negeri Republik Indonesia Nomor 83 Tahun 2015 Tentang Pengangkatan Dan Pemberhentian Perangkat Desa Peraturan Desa Karang Sari No. 04 Tahun 2018 Tentang Susunan Organisasi dan Tata Kerja Pemerintahan Peraturan Kepala Desa Nomor 5 Tahun 2018 Tentang Seksi Perangkat Desa. 